\title{
Carbon storage and sequestration potential of selected tree species in India
}

\author{
Meenakshi Kaul • G. M. J. Mohren • V. K. Dadhwal
}

Received: 19 November 2009 / Accepted: 19 April 2010 /

Published online: 30 April 2010

(C) The Author(s) 2010. This article is published with open access at Springerlink.com

\begin{abstract}
A dynamic growth model (CO2FIX) was used for estimating the carbon sequestration potential of sal (Shorea Robusta Gaertn. f.), Eucalyptus (Eucalyptus Tereticornis Sm.), poplar (Populus Deltoides Marsh), and teak (Tectona Grandis Linn. f.) forests in India. The results indicate that long-term total carbon storage ranges from 101 to $156 \mathrm{Mg} \mathrm{Cha}{ }^{-1}$, with the largest carbon stock in the living biomass of long rotation sal forests $\left(82 \mathrm{Mg} \mathrm{Cha}^{-1}\right)$. The net annual carbon sequestration rates were achieved for fast growing short rotation poplar $\left(8 \mathrm{Mg} \mathrm{Cha}^{-1} \mathrm{yr}^{-1}\right)$ and Eucalyptus (6 $\left.\mathrm{Mg} \mathrm{Cha}{ }^{-1} \mathrm{yr}^{-1}\right)$ plantations followed by moderate growing teak forests $\left(2 \mathrm{Mg} \mathrm{Cha}^{-1} \mathrm{yr}^{-1}\right)$ and slow growing long rotation sal forests $\left(1 \mathrm{Mg} \mathrm{Cha}^{-1} \mathrm{yr}^{-1}\right)$. Due to fast growth rate and adaptability to a range of environments, short rotation plantations, in addition to carbon storage rapidly produce biomass for energy and contribute to reduced greenhouse gas emissions. We also used the model to evaluate the effect of changing rotation length and thinning regime on carbon stocks of forest ecosystem (trees + soil) and wood products, respectively for sal and teak forests. The carbon stock in soil and products was less sensitive than carbon stock of trees to the change in rotation length. Extending rotation length from the recommended 120 to 150 years increased the average carbon stock of forest ecosystem (trees + soil) by $12 \%$. The net primary productivity was highest $\left(3.7 \mathrm{Mg} \mathrm{ha}^{-1} \mathrm{yr}^{-1}\right)$ when a 60 -year rotation length was applied but decreased with increasing rotation length (e.g., $1.7 \mathrm{Mg} \mathrm{ha}^{-1} \mathrm{yr}^{-1}$ ) at 150 years. Goal of maximum carbon storage and production of more valuable saw logs can be achieved from longer rotation lengths. 'No thinning' has the largest biomass, but from an economical perspective, there will be no wood available from thinning operations to replace
\end{abstract}

M. Kaul $(\square) \cdot$ G. M. J. Mohren

Forest Ecology and Forest Management Group (FEM), Centre for Ecosystem Studies, Wageningen University, P. O. Box 47, NL -6700 AA Wageningen, The Netherlands e-mail: kaul_2000@rediffmail.com

G. M. J. Mohren

e-mail: frits.mohren@wur.nl

V. K. Dadhwal

Indian Institute of Remote Sensing (IIRS), 4 Kalidas Road, Dehradun UA-248001, India

e-mail: vkdadhwal@iirs.gov.in 
fossil fuel for bioenergy and to the pulp industry and such patches have high risks of forest fires, insects etc. Extended rotation lengths and reduced thinning intensity could enhance the long-term capacity of forest ecosystems to sequester carbon. While accounting for effects of climate change, a combination of bioenergy and carbon sequestration will be best to mitigation of $\mathrm{CO}_{2}$ emission in the long term.

Keywords CO2FIX · Eucalyptus · Teak $\cdot$ Poplar $\cdot$ Sal $\cdot$ Forest simulation model $\cdot$ Thinning $\cdot$ Rotation length

\section{Introduction}

Forest vegetation and soils constitute a major terrestrial carbon pool with the potential to absorb and store carbon dioxide $\left(\mathrm{CO}_{2}\right)$ from the atmosphere. The $\mathrm{CO}_{2}$ source and sink dynamics as trees grow, die, and decay are subjected to disturbance and forest management. Evidence of climate change linked to human-induced increase in greenhouse gas (GHG) concentrations is well-documented in international studies (IPCC 2001, 2007). To contribute to reduction of GHG emissions, and to partly offset deforestation, the Kyoto protocol (KP) explicitly considered reforestation and afforestation activities for carbon sequestration accounting (IPCC 2007). The recognized importance of forests in mitigating climate change has led countries to study their forest carbon budgets and initiate the assessment of enhancing and maintaining carbon sequestration of their forests resource. The total global potential for afforestation and reforestation activities for the period 1995-2050 is estimated to be between 1.1 and $1.6 \mathrm{Pg} \mathrm{C}\left(1 \mathrm{Pg}=\right.$ Peta gram, $\left.10^{15} \mathrm{~g}\right)$ per year, of which $70 \%$ could occur in the tropics (IPCC 2000). Afforestation and reforestation are seen as potentially attractive mitigation strategies, as wood production and carbon (C) storage can be combined. Several carbon budget models of different complexity have been developed and used to account for forest carbon dynamics (e.g. Parton et al. 1987; Kurz et al. 1992; Kimmins et al. 1999; Price et al. 1999; Karjalainen et al. 2002; Peng et al. 2002; Seely et al. 2002; Masera et al. 2003). Some of these studies not only account for the carbon in the forest ecosystem but also for the carbon contained in the harvested wood products (Burshel et al. 1993; Karjalainen et al. 1994, 2002, 2003; Harmon et al. 1996; Pingoud et al. 2001; Skog and Nicholson 1998; Winjum et al. 1998; Masera et al. 2003).

Studies of Indian forests as part of the national forest carbon balance (e.g. Ravindranath et al. 1997; Haripriya 2000; Chhabra and Dadhwal 2004; Manhas et al. 2006; Gupta 2009; Kaul et al. 2009) have examined strata and state/regional forest area changes. Their results range from the finding that the forests are a major source to the finding that they are a sink for atmospheric carbon. Using a simple book-keeping approach, Chhabra and Dadhwal (2004) estimated that the cumulative net carbon flux from Indian forests (1880-1996) due to land use changes (deforestation, afforestation and phytomass degradation) was $5.4 \mathrm{Pg} \mathrm{C}$ with the mean annual net $\mathrm{C}$ flux as $9.0 \mathrm{Tg}\left(1 \mathrm{Tg}=\right.$ Tera gram, $\left.10^{12} \mathrm{~g}\right) \mathrm{C} \mathrm{yr}^{-1}$. Kaul et al. (2009) indicated that the Indian forest sector acted as a small source of carbon during the period 1982-1992 with the annual net carbon flux due to land use changes estimated as $5.65 \mathrm{Tg} \mathrm{Cyr}^{-1}$. For India, a marginal net sequestration of $5 \mathrm{Tg} \mathrm{C}$ for the reference year 1986 and of $1.09 \mathrm{Tg} \mathrm{C}$ for 2002 has been estimated by Ravindranath et al. (1997) and Kaul et al. (2009) respectively. The mitigation potential of the forestry sector, based on a biomass-demand based scenario, using short or long-term commercial forestry option is estimated to be $122 \mathrm{Tg}$ C for the period 2000-2012 (Ravindranath et al. 2002). Further, species-specific carbon sequestration potential studies have provided entirely different 
estimates depending upon various factors like weather conditions, location and management activities (Negi and Chauhan 2002; Negi et al. 2003; Singh 2003).

United Nations Framework Convention on Climate Change (UNFCCC) has recognized the importance of plantation forestry as a greenhouse gas mitigation option, as well as the need to monitor, preserve and enhance terrestrial carbon stocks (Updegraff et al. 2004). In addition, production from plantation forests may relieve pressure on timber extraction from natural forests, and thus contribute to forest conservation. Globally, the annual planting rate is 4.5 million ha, with Asia and South America accounting for 89\% (Fang et al. 2007). Large parts of India offer good growing conditions, good rainfall and water resources, a tropical climate and ample sunshine, so that trees may grow fast. Forest plantations constitute a very important part of the forest resources as large proportion of wood produced in India comes from tree plantations established both within and outside the forest reserves. About 36 million ha of degraded and non-forest lands have been afforested during the period 1951 to 2002, as shown in Fig. 1 (FSI 1999; Forestry \& Wildlife Statistics of India 2004). According to the records of the National Afforestation and Eco-development Board (NAEB) of the Ministry of Environment and Forests of the Government of India, the cumulative area under forest plantations up to 2005-2006 was 42.17 million ha (Pandey 2008). Using recent remote-sensing based estimates of tree cover and growing stock outside forests in India, the estimated 2.68 billion trees outside forests contribute to an additional national average tree carbon density of $4 \mathrm{Mg} \mathrm{Cha}^{-1}$ in non-forest area, in comparison to an average density of $43 \mathrm{Mg} \mathrm{Cha}^{-1}$ in forests (Kaul et al. 2010a). However, there is a large variation in the carbon sequestration potential of different plantation species and there are varying estimates of the carbon sequestration rates of common plantation species (FAO 2003; Negi and Chauhan 2002).

Soil organic carbon (SOC) also plays a very significant role in the global carbon cycle, as it is the largest terrestrial carbon pool. Soil can be a source $\left(\mathrm{CO}_{2}, \mathrm{CH}_{4}\right.$ and $\left.\mathrm{N}_{2} \mathrm{O}\right)$ or sink $\left(\mathrm{CO}_{2}\right.$ and $\left.\mathrm{CH}_{4}\right)$ of greenhouse gases depending on land use and management (Lal 1999). The total SOC pools in Indian forests have been estimated as $4.13 \mathrm{Pg} \mathrm{C}$ (top $50 \mathrm{~cm}$ ) to 6.81

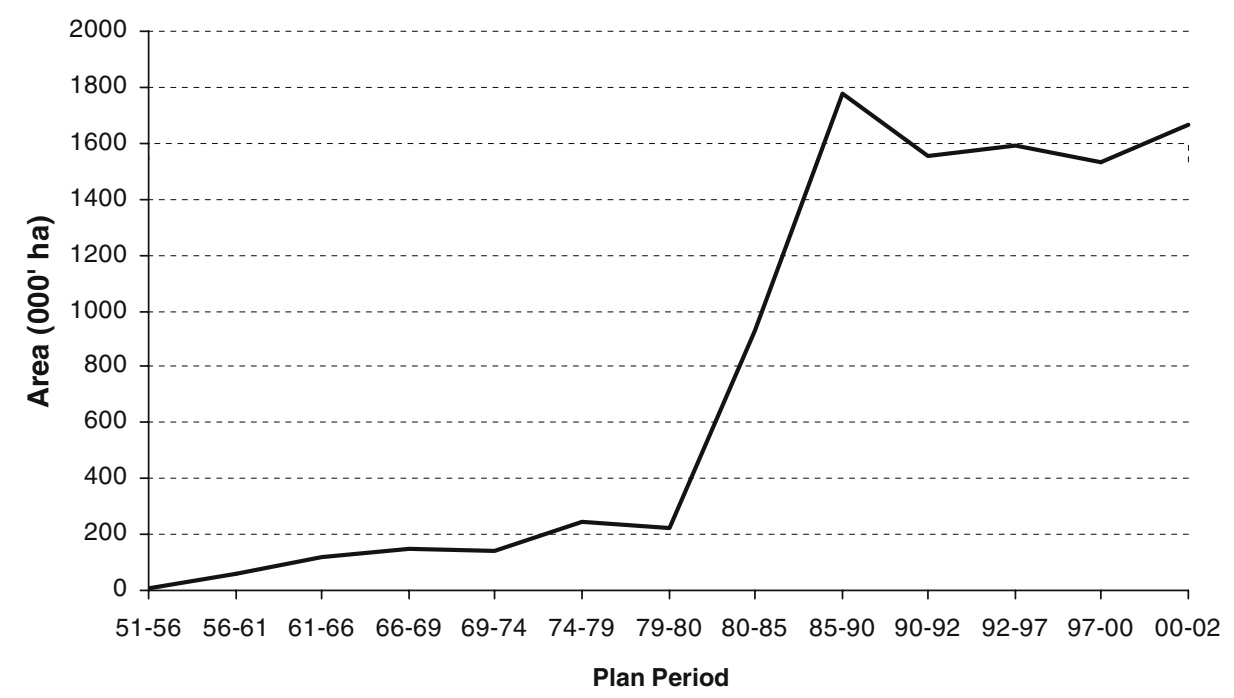

Fig. 1 Indian Government economic plan-wise annual rate of plantation (1951-2002). Source (FSI 1999, Forestry \& wildlife statistics of India 2004) 
Pg C (top $1 \mathrm{~m}$ soil depths) for the period 1980-1982 (Chhabra et al. 2002). Based on different forest types in India, the national average of soil organic carbon per ha in forest soil was estimated as $183 \mathrm{Mg} \mathrm{Cha}^{-1}$ (Jha et al. 2003).

To assess the potential of additional carbon sequestration by forest management as part of climate change mitigation strategies, it is necessary to understand the carbon storage in forest biomass, soil and wood products, and the interactions between these compartments. Forest management interferes with carbon storage through choice of rotation length, thinning intensity, stand density and spacing, and silvicultural practices such as coppicing and soil preparation etc., and may cause both increases and decreases in carbon stocks in forest biomass. For a proper evaluation of the potential for carbon storage, it is important to distinguish these options in relation to species and silvicultural treatment.

In this study, we used a dynamic model of carbon storage in forests, CO2FIX v. 3.1 (Masera et al. 2003; Schelhaas et al. 2004) to investigate the full carbon cycle of some important species in natural and short rotation plantation forestry in India. These are Sal (Shorea robusta Gaertn. F.) as representative of natural forests, and teak (Tectona grandis Linn. F.), Eucalyptus (Eucalyptus tereticornis Sm.) and poplar (Populus deltoides Marsh) as exotic plantation species. The CO2FIX model also examines the effect of various thinning intensities and altered rotation length on the standing biomass and carbon stock of long rotation and short rotation plantation forests.

\section{Materials \& methods}

\subsection{The model CO2FIX}

The CO2FIX stand level simulation model is a tool which quantifies the carbon stocks and fluxes in forest biomass, the soil organic matter and the wood products chain, essentially using a bookkeeping approach in which biomass accumulation is converted to carbon sequestration and storage. The model calculates the carbon balance with a time-step of 1 year. Basic input is stem volume growth and corresponding allocation patterns to the other tree compartments (foliage, branches and roots). Carbon stocks in living biomass are calculated as the balance between growth (accumulation) on the one hand and turnover, mortality, harvest and decomposition on the other hand (Masera et al. 2003; Schelhaas et al. 2004). The model is divided into six main modules: biomass, soil (litter and humus), wood products, bioenergy, and both financial and carbon accounting. Figure 2 illustrates the modular structure of the model. Previously, we used the bioenergy module of the CO2FIX model to compare the carbon mitigation potential of afforestation and fossil fuel substitution for two land use categories (forest land and non-forest land) and two management practices (short vs. long rotation) (Kaul et al. 2010b).

For the soil carbon module, the litter is grouped as non-woody litter (foliage and fine roots), fine woody litter (branches and coarse roots) and coarse woody litter (stems and stumps). Litter is produced in the biomass module through biomass turnover, natural mortality (mortality due to senescence and competition), mortality due to logging and harvesting of trees, and logging slashes. Litter remaining from thinning and final harvest is distributed over the decomposition compartments of extractives, celluloses and lignin-like compounds according to chemical composition. The principle of the product module is that it tracks the carbon from harvesting to final decay. The harvested wood is allocated to different product groups depending upon the type of use of tree species, and taking into account the use of processing losses to other product groups. 


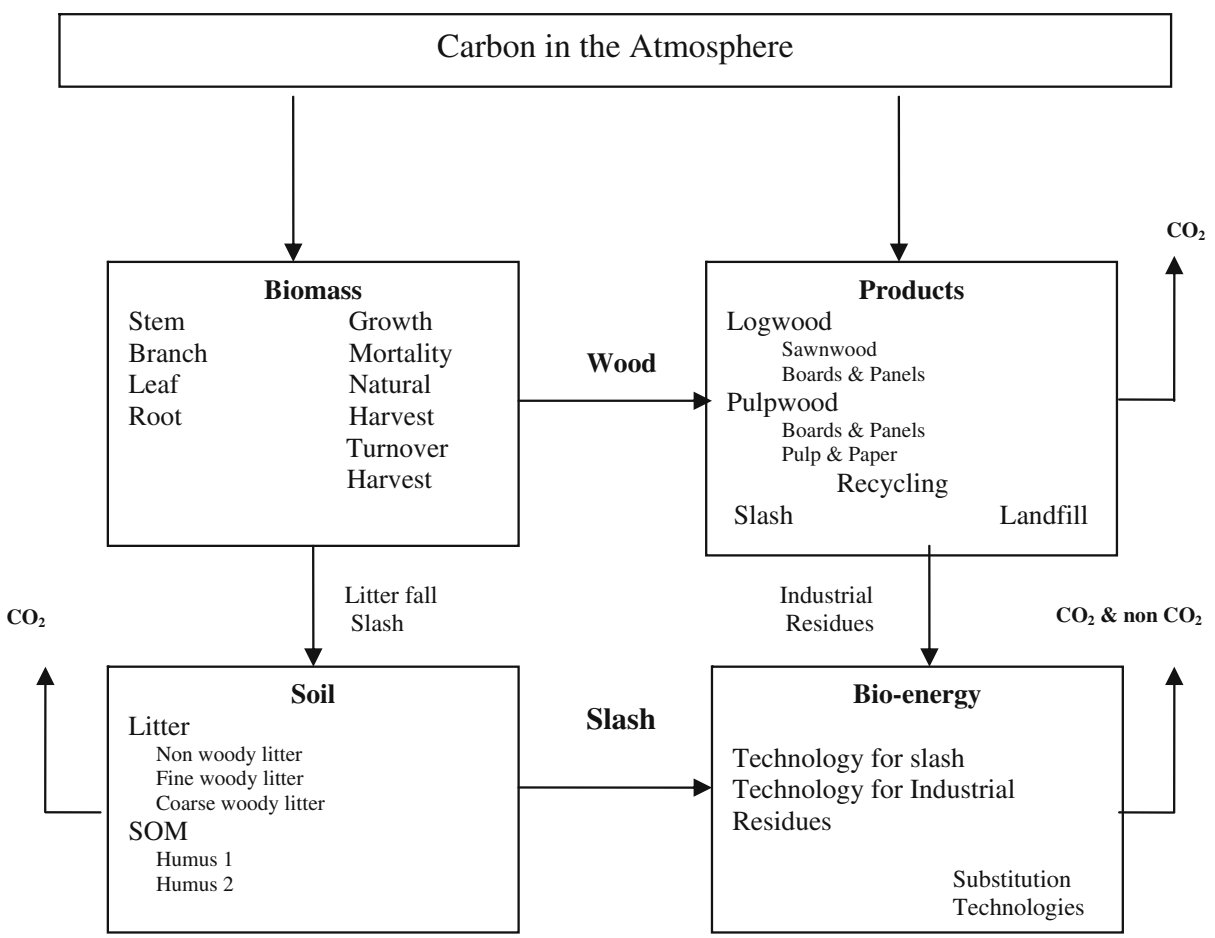

Fig. 2 Structure of CO2FIX V3 model, including major compartments used in each module, processes affecting the compartments (right hand side in the boxes), major flows between modules and fluxes of $\mathrm{CO}_{2}$ from modules to the atmosphere

Products are assumed to decay with a certain fraction per year depending upon the life span estimates. Carbon is released to the atmosphere when products in landfill decompose or through combustion when products are used for fuelwood. (Schelhaas et al. 2004). The products module is based on Karjalainen et al. (1994); a more detailed version has been applied for the European forest sector (Karjalainen et al. 2002; Eggers 2002). The CO2FIX model has been described in detail by Nabuurs and Schelhaas (2002); Masera et al. (2003) and Schelhaas et al. (2004). The full CO2FIX model is freely available from the web at http://www.efi.int/projects/casfor, together with numerous examples.

\subsection{Simulation approach}

The model was parameterized for the simulations using published data on growth rate and biomass amounts (Table 1). The carbon content of dry matter was calculated assuming that the carbon fraction in live biomass is $50 \%$. Wood densities for all the species were derived from Haripriya (2000). The litter production rate for the separate biomass compartments was derived by multiplying the biomass stock with corresponding turnover coefficients (per year).

We derived these turnover coefficients for foliage, branches and roots from Negi (1984); Jha (1995); Bargali et al. (1992) and Lodhiyal et al. (1995); Lodhiyal and Lodhiyal (1997) for sal, teak, Eucalyptus and poplar respectively (Table 1a). Growth of foliage, branches and roots is incorporated as an additional allocation of dry matter increment relative to the 
Table 1 Summary of parameters used in simulating carbon dynamics of Eucalyptus, Poplar, Sal \& Teak

\begin{tabular}{lcccc}
\hline \multicolumn{1}{c}{ Parameter } & Eucalyptus $^{\mathbf{a}}$ & Poplar $^{\mathbf{b}}$ & Sal $^{\mathbf{c}}$ & Teak $^{\mathbf{d}}$ \\
\hline Basic Wood & & & & \\
Density $\left(\mathrm{Kg} \mathrm{m}^{-3}\right)$ & 495 & 380 & 672 & 643 \\
\hline (a) Turnover rates (1/yr) & & & \\
\hline Foliage & 0.6 & .95 & 1 & 1 \\
Branches & .02 & 0.1 & 0.01 & .04 \\
Roots & .05 & 0.04 & 0.01 & .25 \\
\hline
\end{tabular}

(b) Ratio of dry weight increase relative to dry weight increase of stem (dimensionless)

\begin{tabular}{|c|c|c|c|c|c|c|c|c|}
\hline \multicolumn{9}{|c|}{ Eucalyptus $^{\mathrm{a}}$} \\
\hline Stand age (years) & 0 & 2 & 3 & 4 & 5 & 6 & 7 & 8 \\
\hline Foliage & 0.3 & 0.44 & 0.40 & 0.38 & 0.37 & 0.32 & 0.56 & 0.58 \\
\hline Branch & 0.25 & 0.22 & 0.18 & 0.18 & 0.21 & 0.28 & 0.43 & 0.58 \\
\hline Root & 0.3 & 0.43 & 0.58 & 0.49 & 0.36 & 0.31 & 0.47 & 0.37 \\
\hline \multicolumn{9}{|c|}{ Poplar $^{\mathrm{b}}$} \\
\hline Stand age (years) & 1 & 2 & 3 & 4 & 5 & 6 & 7 & 8 \\
\hline Foliage & 0.45 & 0.43 & 0.55 & 0.64 & 0.8 & 0.98 & 1.13 & 1.33 \\
\hline Branch & 0.4 & 0.41 & 0.34 & 0.32 & 0.4 & 0.57 & 0.69 & 0.97 \\
\hline Root & 0.4 & 0.42 & 0.43 & 0.44 & 0.46 & 0.53 & 0.59 & 0.69 \\
\hline \multicolumn{9}{|c|}{ Sal $^{\mathrm{c}}$} \\
\hline
\end{tabular}

\begin{tabular}{|c|c|c|c|c|c|c|c|c|c|c|}
\hline $\begin{array}{l}\text { Stand } \\
\text { age }\end{array}$ & 0 & 22 & 33 & 36 & 43 & 47 & 52 & 55 & 91 & 93 \\
\hline Foliage & 1 & 0.73 & 0.64 & 0.94 & 1.02 & 1.01 & 1.12 & 0.98 & 0.75 & 0.85 \\
\hline Branch & 0.2 & 0.18 & 0.15 & 0.17 & 0.16 & 0.16 & 0.16 & 0.15 & 0.14 & 0.14 \\
\hline Root & 0.4 & 0.39 & 0.3 & 0.34 & 0.31 & 0.32 & 0.31 & 0.29 & 0.27 & 0.37 \\
\hline \multicolumn{11}{|c|}{ Teak $^{d}$} \\
\hline Stand age & & 1 & & 5 & 11 & \multicolumn{2}{|c|}{18} & 24 & & 30 \\
\hline Foliage & & 0.26 & & 0.63 & 0.5 & \multicolumn{2}{|c|}{0.38} & 0.32 & & 0.5 \\
\hline Branch & & 0.44 & & 0.44 & 0.33 & \multicolumn{2}{|c|}{0.38} & 0.32 & & 0.32 \\
\hline Root & & 0.44 & & 0.48 & 0.63 & \multicolumn{2}{|c|}{0.6} & 0.77 & & 0.82 \\
\hline
\end{tabular}

(c) Fraction removed during thinning or harvest

$\begin{array}{lllllllllllllll}\text { Age (years) } & 8 & 9 & 10 & 16 & 20 & 24 & 30 & 40 & 50 & 60 & 70 & 90 & 100 & \mathbf{1 2 0}\end{array}$

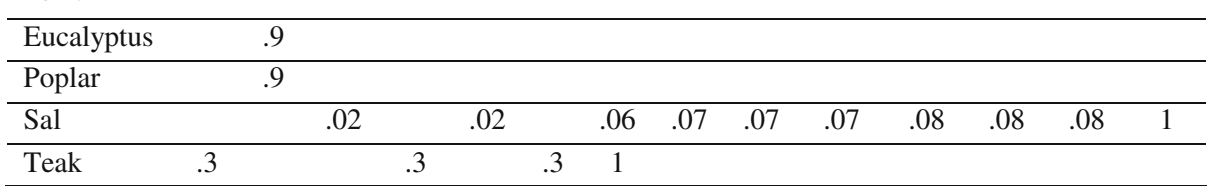

Estimated from ${ }^{\text {a }}$ Bargali et al. (1992); ${ }^{\mathrm{b}}$ Lodhiyal et al. (1995); Lodhiyal and Lodhiyal (1997); ${ }^{\mathrm{c}}$ Negi (1984); d Jha (1995)

stem wood derived from the ratio of net primary productivity (NPP) per component, estimated by Negi (1984); Jha (1995); Bargali et al. (1992) and Lodhiyal et al. (1995); Lodhiyal and Lodhiyal (1997) for sal, teak, Eucalyptus and poplar respectively (Table 1b).

For each tree species a general management regime was defined, which consists of the ages when thinning takes place as shown in Table 1c. In case of Eucalyptus and poplar, no thinning was done and final harvest took place at 9 years of age where $90 \%$ of the total volume was removed. In the case of teak forest, in each thinning $30 \%$ of the total volume was extracted at the age of 8, 16 and 24 years, depending on the thinning practices in India (Negi 1996; Bebarta 1999). Sal forests in India are harvested on a 120-year rotation cycle, 
applying thinning every 10 years, in line with standard practices (Tewari 1995a) as given in Table 1c. The mean annual volume increment is $4.9 \mathrm{~m}^{3} /$ ha (Negi 1984). In natural sal stands, it was assumed that there was no competition effect within the cohort and a moderate natural mortality of $2 \%$ per year was assumed for the period of 20 years.

The Current Annual Increment (CAI) was derived from the yield tables and computed from stem biomass using wood density (Table 2). The CAI for sal and teak was taken from local growth and yield tables (Tewari 1995a, b). In case of poplar, age-related stem biomass data from Lodhiyal et al. (1995) and Lodhiyal and Lodhiyal (1997) was used, and stem biomass was converted to stem volume using a wood density of $380 \mathrm{~kg} \mathrm{~m}^{-3}$ (Haripriya 2000). For Eucalyptus the CAI was taken from (Dwivedi 1994).

The soil module of CO2FIX model uses climate data about precipitation, evapotranspiration and mean monthly temperatures. Initial soil and carbon data were derived from the procedure as reported by Masera et al. (2003). Climate data was used from http://www. indiastat.com. Degree days (above zero, $0^{0}$ ) were calculated from the mean monthly temperatures using the method described by Liski et al. (2003). Different simulation periods were adopted for different systems, therefore for long rotations we use a 300-year simulation period and for short rotation exotic species, a 200 year simulation period was used.

In the product module, harvested wood was divided into logwood, pulpwood and harvest residues and foliage was categorized as slash (Fig. 2, Table 3). Pulpwood and logwood were distributed to the commodities sawn wood, boards, pulp and paper and fuel wood. The fuel wood is automatically updated in such a way that the sum of the fractions is 1. The CO2FIX also allows for the specification of the conversion efficiency of main product and usage of residuals as firewood or other category of products. The lower the loss in carbon (in the form of wood products) the higher is the processing efficiency. A conversion efficiency of conversion 0.5 to 0.7 was adopted (Buekering and Sharma 1998; Haripriya 2001). Production losses were reallocated to lower grade production lines, used as fuel wood or dumped at the mill site. It is difficult to ascertain the half life for various products as there are different estimates across studies (Karjalainen et al. 1994; Harmon et al. 1996;

Table 2 Current Annual Increment as a function of stand age for Eucalyptus, Poplar, Sal \& Teak

\begin{tabular}{|c|c|c|c|c|c|c|c|c|c|}
\hline \multicolumn{2}{|c|}{ Eucalyptus $^{\mathrm{a}}$} & \multicolumn{2}{|c|}{ Poplar ${ }^{b}$} & \multicolumn{4}{|l|}{$\mathrm{Sal}^{\mathrm{c}}$} & \multicolumn{2}{|c|}{ Teak $^{\mathrm{d}}$} \\
\hline Age & CAI $\left(\mathrm{m}^{3} / \mathrm{ha} / \mathrm{yr}\right)$ & Age & CAI $\left(\mathrm{m}^{3} / \mathrm{ha} / \mathrm{yr}\right)$ & Age & CAI $\left(\mathrm{m}^{3} / \mathrm{ha} / \mathrm{yr}\right)$ & Age & CAI $\left(\mathrm{m}^{3} / \mathrm{ha} / \mathrm{yr}\right)$ & Age & CAI $\left(\mathrm{m}^{3} / \mathrm{ha} / \mathrm{yr}\right)$ \\
\hline 1 & 7.5 & 1 & 16.56 & 10 & 4.3 & 65 & 9.5 & 5 & 5 \\
\hline 2 & 10 & 2 & 23.7 & 15 & 5.1 & 70 & 9.6 & 10 & 8.5 \\
\hline 3 & 20 & 3 & 26.58 & 20 & 5.8 & 75 & 9.7 & 15 & 10.5 \\
\hline 4 & 26.5 & 4 & 27.68 & 25 & 6.4 & 80 & 9.7 & 20 & 9.5 \\
\hline 5 & 24 & 5 & 27.4 & 30 & 7 & 85 & 9.7 & 25 & 8.5 \\
\hline 6 & 12.3 & 6 & 26.5 & 35 & 7.5 & 90 & 9.6 & 30 & 7.5 \\
\hline 7 & 11.6 & 7 & 25.9 & 40 & 8 & 95 & 9.5 & 35 & 7 \\
\hline 8 & 8 & 8 & 23 & 45 & 8.4 & 100 & 9.3 & 40 & 6.5 \\
\hline \multirow[t]{4}{*}{9} & 6.7 & 9 & 19.2 & 50 & 8.7 & 105 & 9 & 45 & 6 \\
\hline & & & & 55 & 9 & 110 & 8.7 & & \\
\hline & & & & 60 & 9.3 & 115 & 8.4 & & \\
\hline & & & & & & 120 & 8 & & \\
\hline
\end{tabular}

\footnotetext{
${ }^{a}$ Dwivedi (1994); ${ }^{b}$ Estimated from Lodhiyal et al. (1995); Lodhiyal and Lodhiyal (1997); ${ }^{c, d}$ Tewari (1995a,b)
} 
Table 3 Product allocation for thinning and harvesting

\begin{tabular}{|c|c|c|c|}
\hline & Logwood & Pulpwood & Slash \\
\hline \multicolumn{4}{|l|}{ Eucalyptus } \\
\hline Stem-harvesting & 0.02 & 0.5 & 0.48 \\
\hline Branch & 0.02 & .5 & .48 \\
\hline Foliage & 0 & 0 & 1 \\
\hline \multicolumn{4}{|l|}{ Poplar } \\
\hline Stem-harvesting & 0.02 & 0.5 & .48 \\
\hline Branch & .05 & .6 & .35 \\
\hline Foliage & 0 & 0 & 1 \\
\hline \multicolumn{4}{|l|}{ Sal } \\
\hline Stem-harvesting & 0.8 & 0 & 0.20 \\
\hline Branch & 0.8 & 0 & 0.20 \\
\hline Foliage & 0 & 0 & 1 \\
\hline \multicolumn{4}{|l|}{ Teak } \\
\hline Stem-harvesting & 0.8 & 0 & 0.2 \\
\hline Branch & 0.8 & 0 & 0.2 \\
\hline Foliage & 0 & 0 & 1 \\
\hline
\end{tabular}

Ravindranath et al. 1997). To indicate the life of wood products, the produced products were divided into different life span categories.

For this study, the ratio of partitioning to long-, medium- and short-term products and their half life were adopted from a study by Haripriya (2001) in which a number of original references are also cited. The half life span $(50 \%$ of the original products produced in one year still in use) of products was one year for short, 10 year for medium and 20 years for long lifespan products. The residues from the pulping process are largely burnt and released into the atmosphere as $\mathrm{CO}_{2}$. Of the remaining volume after debarking, $5 \%$ of the carbon is lost as process energy during conversion of pulpwood to mechanical pulp and $50 \%$ is lost during conversion to chemical pulp (Haripriya 2001).

To address the effect of thinning intensity and changing rotation length on carbon stock, we study teak and sal forests as an example, respectively. Thinning operations provide an important source of wood for the forest industry and increase the growth of the remaining trees in a stand. At the end of the applied rotation period, stands were clear-felled and stem wood was removed from the site. The timing and intensity of thinning was based on the current management recommendations (i.e., based on a function of basal area and dominant height) (Bebarta 1999). Three different thinning regimes were examined: 'low thinning', 'one heavy thinning' and 'no thinning'. For subsequent thinning operations in the 'low thinning' the intensity was determined by the development of the basal area. In "low thinning" operations, only $10 \%$ of the standing volume was removed at the age of 5 and 15 years followed by complete harvest at 30 years of age. In "one heavy thinning" operation, $70 \%$ of the standing volume was removed at 15 years of age with final harvest at 30 years and in the 'no thinning' cases, there was no interim harvesting of trees before the final cut at a rotation length of 30 years.

The carbon pool in forest biomass (trees+soil) and harvested wood products was analysed for the changed rotation of 60,90 and 150 years of age, taking sal forests as an example for natural forests. At the end of the rotation age, the stem wood was fully removed from the site and the rest of the biomass was left as harvest residue. 


\section{Description of the species and study area}

The four species addressed in this study are natural sal (Shorea robusta Gaertn. f.) and three exotic species: Eucalyptus (Eucalyptus tereticornis Sm.), poplar (Populus deltoides Marsh) and teak (Tectona grandis Linn. f.).

3.1. For Eucalyptus and poplar plantations, we have focused on the Terai region of the Central Himalaya (a level area of superabundant water). The climate of the Terai belt is sub-tropical monsoon, with a long dry season from early October to mid-June and a wet season from mid-June to early October. Of the average annual rainfall of $1593 \mathrm{~mm}$ (average for 1985-1989), about 86\% falls from mid-June to September. The mean monthly temperature ranges from $14.4^{\circ} \mathrm{C}$ (January) to $31.3^{\circ} \mathrm{C}$ (June). The soil is deep and fertile, moist alluvial loam, conspicuously free from boulders and gravels. The plantation density of Eucalyptus was 2,000 trees per ha, whereas the tree density in poplar stands was 400 trees per ha. The rotation length for Eucalyptus and poplar is 9 years. In the Terai belt, previous land use was natural sal mixed broad leaved forest (Champion and Seth 1968) which was clear felled before establishing plantations. In the Terai belt, the foresters have been raising poplar plantations for the last three decades and presently the plantation covers an area of about 16,000 ha under various poplar clones (Lodhiyal and Lodhiyal 1997) on short rotations of 6-8 years, with a high productivity of $20 \mathrm{~m}^{3} \mathrm{ha}^{-1} \mathrm{yr}^{-1}$.

3.2. In India, sal (fam. Dipterocarpaceae), a fairly large deciduous tree is found in forests covering about 12 million ha, representing about $16 \%$ of the total forested area (Tewari 1995a). Sal is the dominant species forming nearly pure stands, due to its resistance to fire, coppicing ability and adaptability to various conditions of soil and site. Sal is one of the most important timber-yielding plants in India, and is known for its heavy, hard and tough wood. Sal occurs in mixed forests with other trees in Himalayan foothills and central Indian belts. This type occurs throughout northern India except in the dry north-west and much of the wet north-east. The type is important is Uttar Pradesh, Bihar, Assam, Orissa, Madhya Pradesh, and Bengal, and constitutes their most important forests. The mean annual temperature typically lies between $21^{\circ} \mathrm{C}$ and $26^{\circ} \mathrm{C}$. The typical rainfall is around $1,300 \mathrm{~mm}$ to $1,500 \mathrm{~mm}$.

3.3. Teak, a natural species in South Asia, is one of the most widely introduced exotics in tropical countries. In India, it occurs naturally from the eastern parts of Rajasthan in the west to Kerala in the south and Tripura in the north central and eastern parts of the country. Of the net area of teak plantations in 1995, about 94\% lay in tropical Asia, with $44 \%$ in India (Ball et al. 1999). Teak is a fine quality timber-yielding deciduous species particularly suitable for rapid production of large volumes of timber, poles and fuel wood. Pure teak plantations (of 1, 5, 11, 18, 24 and 30 years old) raised in moist deciduous forests in Northern India (in Haldwani) was selected for study (Jha 1995). The soil is of a well-drained sandy loam type, reddish brown in colour. The climate is a typical monsoon one, showing three distinct seasons: a hot dry summer (March to June), a warm humid rainy season (July to October), and a cool dry winter (November to February) (Jha 1995). Average annual rainfall is $762 \mathrm{~mm}$ and over $90 \%$ of this occurs during the rainy season.

For the purposes of this study, the model was parameterized for four different forest species representing tropical dry and moist deciduous forests and plantations of short rotation species like Eucalyptus and poplar. The study sites for natural sal forests were situated in dry tropical regions of northern India, East \& West Dehradun forest divisions 
while for plantations the sites were located between $29^{\circ} 3^{\prime}$ and $29^{\circ} 12^{\prime} \mathrm{N}$ latitude and $79^{\circ} 20^{\prime}$ and $79^{\circ} 23^{\prime} \mathrm{E}$ longitude in the Terai belt of Central Himalaya.

\section{Results}

The model was tested and validated for four representatives of short and long rotation species. The model-simulated data was compared with the field data of total dry matter (as published in Negi 1984; Lodhiyal et al. (1995); Lodhiyal and Lodhiyal 1997; Bargali et al. 1992 and Jha 1995). The comparison of model-simulated and measured dry matter in four species is given in Fig. 3. A sensitivity study done earlier on for the model showed reasonable model performance. The $95 \%$ confidence interval for the long-term average

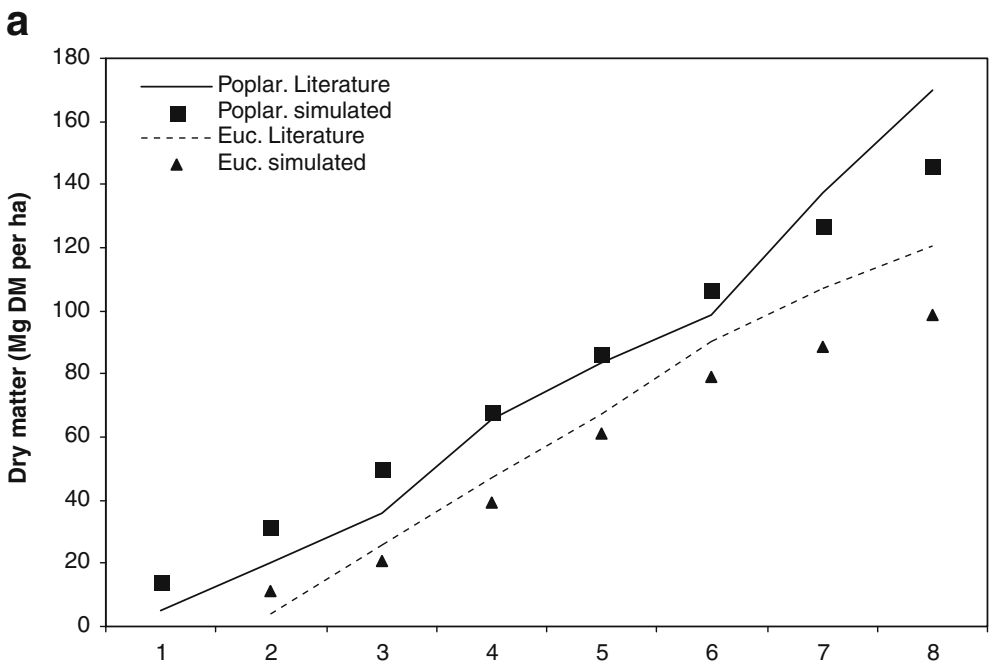

b

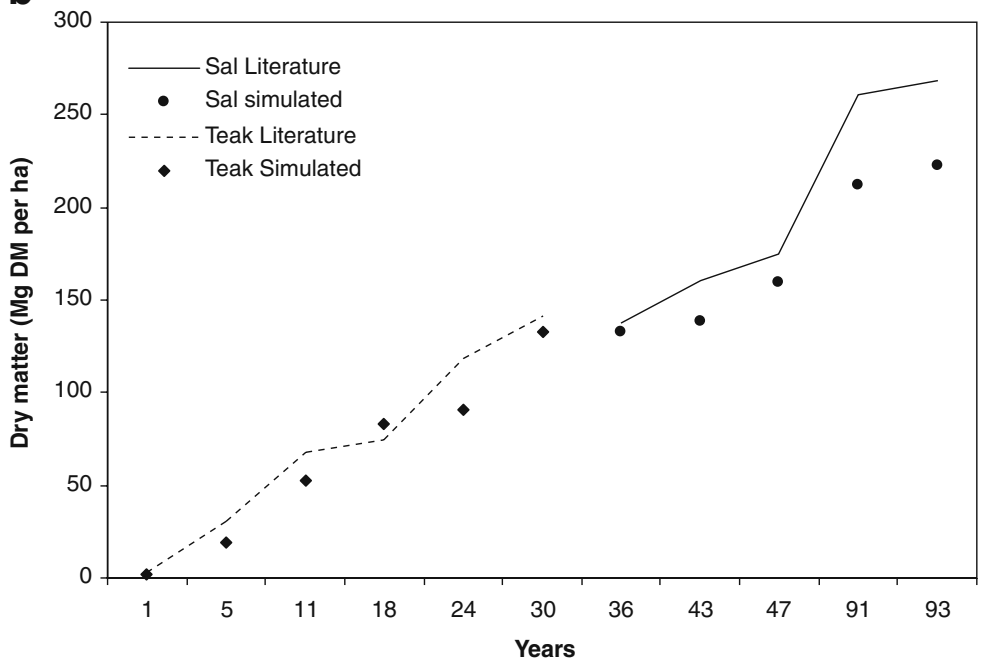

Fig. 3 Simulated and measured dry matter in a Poplar \& Eucalyptus, and b Sal \& Teak 
(after 300 years simulation) carbon stock of the whole system was found to be $\pm 23 \%$. Van der Voet (in: Nabuurs and Mohren 1993) carried out an uncertainty analysis of the model CO2FIX for the Norway spruce forest type in central Europe. For the 32 independent inputs to the model, he found that for the total carbon stock, the average amounted to $316 \mathrm{Mg} \mathrm{C} \mathrm{ha}{ }^{-1}$, whereas the $95 \%$ confidence interval for the long term average ranged from 254 to $403 \mathrm{Mg} \mathrm{C}^{-1}$ which was found to be reasonable. The main uncertainty was caused by uncertainty over the soil organic matter dynamics and the carbon content of dry matter. Since the main input in our study was based on widely accepted growth and yield tables, the present study would probably give a comparable span in results. Although, the growth and yield tables are known to be based on rather old monitoring data which do not represent current site conditions, there are chances of carbon sequestration potential being underestimated. But on the other hand, yield tables also represent fully stocked forests which do not occur very often in practice (Nabuurs and Schelhaas 2002).

\subsection{Long-term average $\mathrm{C}$ stocks}

Using CO2FIX parameters simulation of biomass carbon pools and fluxes was carried out for Eucalyptus (Eucalyptus tereticornis Sm.), poplar (Populus deltoides Marsh), teak (Tectona grandis Linn. F.) and sal (Shorea robusta Gaertn. F.) with rotation length of 9, 9, 30 and 120 years, respectively. Figure 4 shows the long-term (in a simulation period of 300 years) average carbon stocks in soil, products and tree biomass. Although the natural sal forest looses carbon from soil, it still maintains the largest long-term carbon stock in a simulation period of 300 years. The soil compartment displays a slow decrease in stock from $118 \mathrm{Mg} \mathrm{Cha}^{-1}$ in the initial year to 52 after 300 years (a net source of $0.2 \mathrm{Mg} \mathrm{Cha}^{-1}$ per year). The largest carbon stock in biomass and products was achieved in sal forests $\left(101 \mathrm{Mg} \mathrm{Cha}^{-1}\right)$. The long-term average stocks in forest biomass and wood products respectively for Eucalyptus, poplar and teak was 41,55 and $50 \mathrm{Mg} \mathrm{Cha}^{-1}$. The long-term average stocks in wood products were small as compared with the stocks in forest biomass

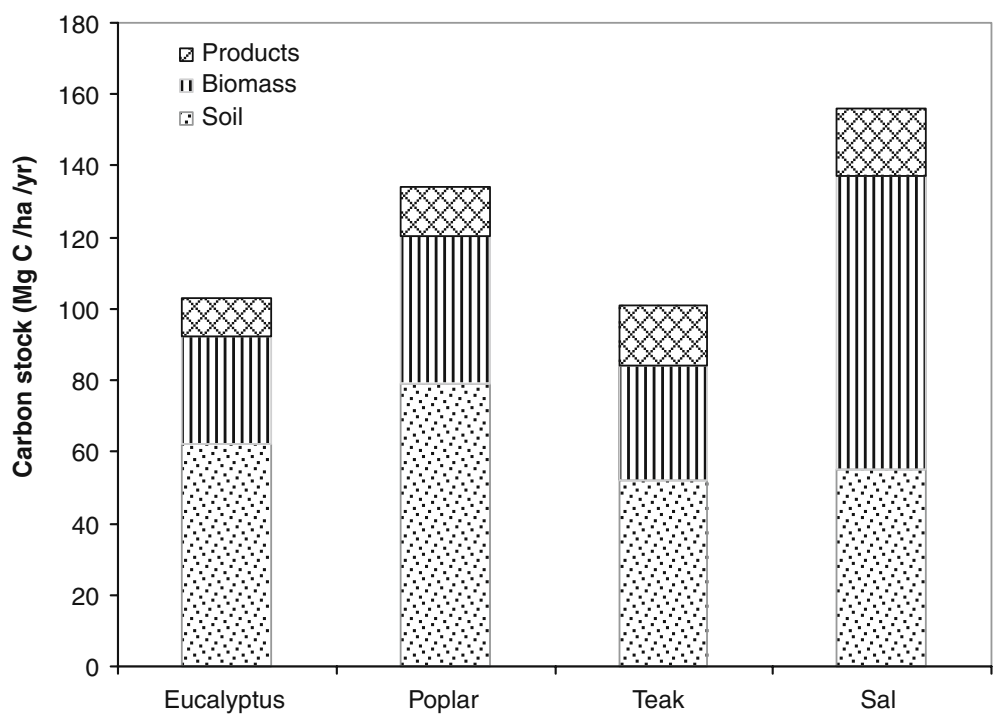

Fig. 4 Long-term average carbon stock in soil, biomass and products of the four forest species 
and soil organic matter. The initial soil $\mathrm{C}$ pool based on the use of Yasso (Liski et al. 2003) model was 75, 67 and $52 \mathrm{Mg} \mathrm{Cha}^{-1}$ for Eucalyptus, poplar and teak, respectively and increased to 85,102 and $73 \mathrm{Mg} \mathrm{Cha}^{-1}$ by the end of the first rotation. This slow increase is mainly due to accumulation of litter and dead wood. Where as in case of natural sal forests, after a slow decrease from $118 \mathrm{Mg} \mathrm{Cha}^{-1}$ from the initial year to $49 \mathrm{Mg} \mathrm{Cha}^{-1}$, soil carbon gradually increases to $117 \mathrm{Mg} \mathrm{Cha}^{-1}$ by the end of first rotation.

The tree species studied differ in the carbon stocks in biomass and soil at the end of the rotation period. At the rotation age, the live biomass disappeared and carbon in products rose to $107 \mathrm{Mg} \mathrm{Cha}^{-1}$ and $50 \mathrm{Mg} \mathrm{Cha}^{-1}$ for sal and teak, respectively. The dry matter at the end of the rotation period was $98 \mathrm{Mg} \mathrm{dm} \mathrm{ha}^{-1}$ for Eucalyptus (9 years), $146 \mathrm{Mg} \mathrm{dm} \mathrm{ha}^{-1}$ for poplar (9 years), $127 \mathrm{Mg} \mathrm{dm} \mathrm{ha}^{-1}$ for teak (30 years) and $312 \mathrm{Mg} \mathrm{dm} \mathrm{ha}^{-1}$ for sal (120 years). This represents a mean annual biomass accumulation of $11 \mathrm{Mg} \mathrm{ha}^{-1} \mathrm{yr}^{-1}$, $16 \mathrm{Mg} \mathrm{ha}^{-1} \mathrm{yr}^{-1}, 4 \mathrm{Mg} \mathrm{ha}^{-1} \mathrm{yr}^{-1}$ and $2.6 \mathrm{Mg} \mathrm{ha}^{-1} \mathrm{yr}^{-1}$ for Eucalyptus, poplar, teak and sal, respectively. Figure 5(a, b, c \& d) shows the time evolution of the carbon stocks in a stand separately for biomass (above and below-ground), soil (including humus, fine and coarse litter) and wood products for each species.

In case of sal forests, the simulation results show that, before the final cut, the amount of carbon in forest biomass and products was limited to 156 and $7 \mathrm{Mg} \mathrm{C} \mathrm{ha}^{-1}$ respectively. By this time, the amount of carbon in the litter layer had increased to $14 \mathrm{Mg} \mathrm{Cha}^{-1}$ and the amount in the stable humus remained stable at $40 \mathrm{Mg} \mathrm{Cha}^{-1}$. After the final cut, the amount of carbon in the forest biomass was reduced to 0 , the amount in the litter layer rose to $70 \mathrm{Mg} \mathrm{Cha}{ }^{-1}$ and the amount in the products rose to $107 \mathrm{Mg} \mathrm{Cha}^{-1}$. The total amount accumulated at the end of the first rotation is the sum of $156 \mathrm{Mg} \mathrm{Cha}^{-1}$ (forest biomass) plus $14 \mathrm{Mg} \mathrm{Cha}^{-1}$ (litter layer) plus $7 \mathrm{Mg} \mathrm{Cha}^{-1}$ (products).

Maximum net annual carbon storage flux was $1 \mathrm{Mg} \mathrm{Cha}^{-1} \mathrm{yr}^{-1}$ for slow-growing longrotation sal forests, 6 and $8 \mathrm{Mg} \mathrm{Cha}^{-1} \mathrm{yr}^{-1}$ for fast-growing short rotation Eucalyptus and poplar forests, respectively and $2 \mathrm{Mg} \mathrm{Cha}^{-1} \mathrm{yr}^{-1}$ for moderate-growing short rotation teak forests. Figure 6 shows the model results on net annual carbon stock since starting year for all the species. The largest carbon sequestration potential was found for poplar and Eucalyptus stands (with peaks in the advancing mean in the range of 3-8.5 $\mathrm{Mg} \mathrm{Cha}^{-1} \mathrm{yr}^{-1}$ ). The smallest potential was found for sal forests (with peak in the advancing mean around 1.2 $\mathrm{Mg} \mathrm{Cha}^{-1} \mathrm{yr}^{-1}$ ). For short rotation species, the amount of carbon offset increases linearly with time the net sink saturated. In case of long rotation sal forests the carbon balance is negative in the beginning (due to enhanced decomposition) but it turns positive after about 34 years of age. Naturally, in all the cases the net sink saturated, causing the advancing mean to diminish to values of around $0.7 \mathrm{Mg} \mathrm{Cha}^{-1} \mathrm{yr}^{-1}$ (ranging from 0.5 to 1.7 to) after 120 years.

\subsection{Opportunities for forest management}

Choice of rotation length and thinning intensity are commonly used to manage timber yield and carbon stocks of forests. These management practices affect all forms of carbon stocks (i.e., tree, soil and wood products). To study the effect of changing rotation length and thinning intensity on the carbon stocks, we discuss the results for natural and plantation forests taking sal and teak as examples in our study and discuss in detail in the following section.

\subsubsection{Effect of changing rotation length}

Figure 7 shows the mean $\mathrm{C}$ stocks in the forest ecosystem and wood products at different rotation lengths. The mean values of above ground biomass for rotation lengths of 60,90 , 
a) Carbon stocks in the Eucalyptus stand

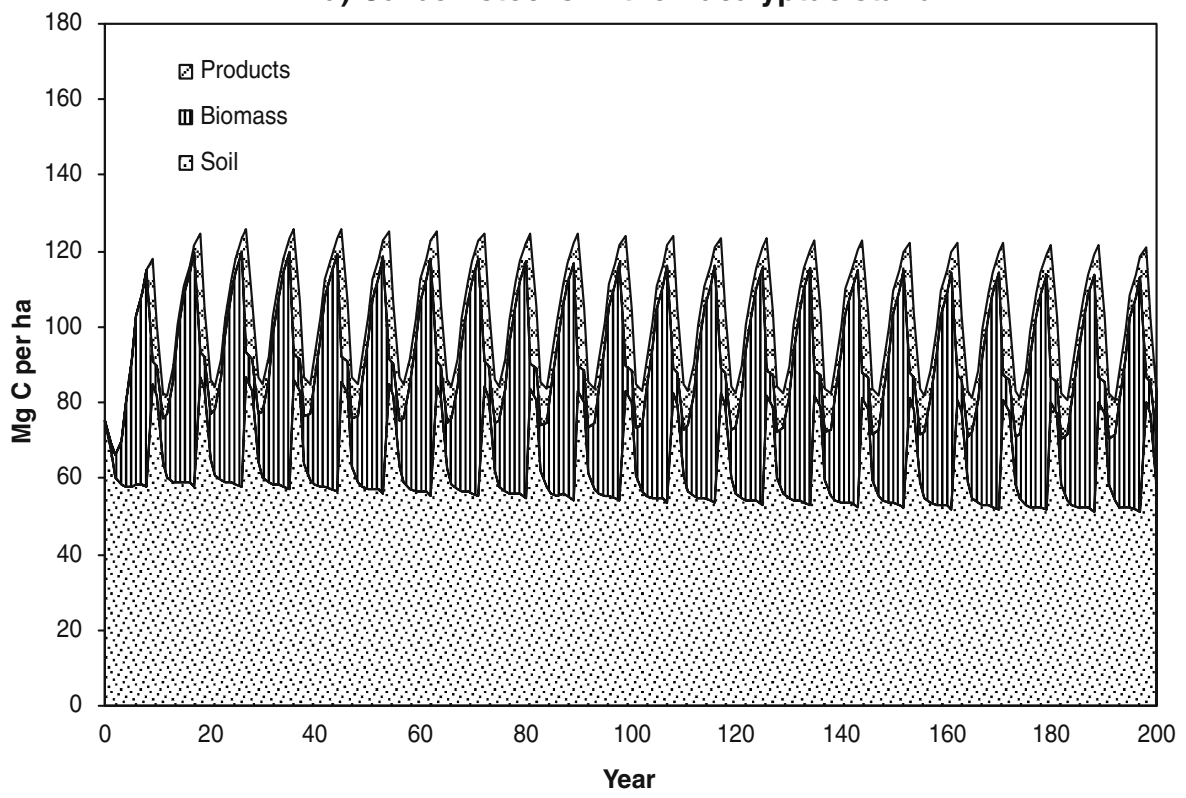

b) Carbon stocks in the Poplar stand

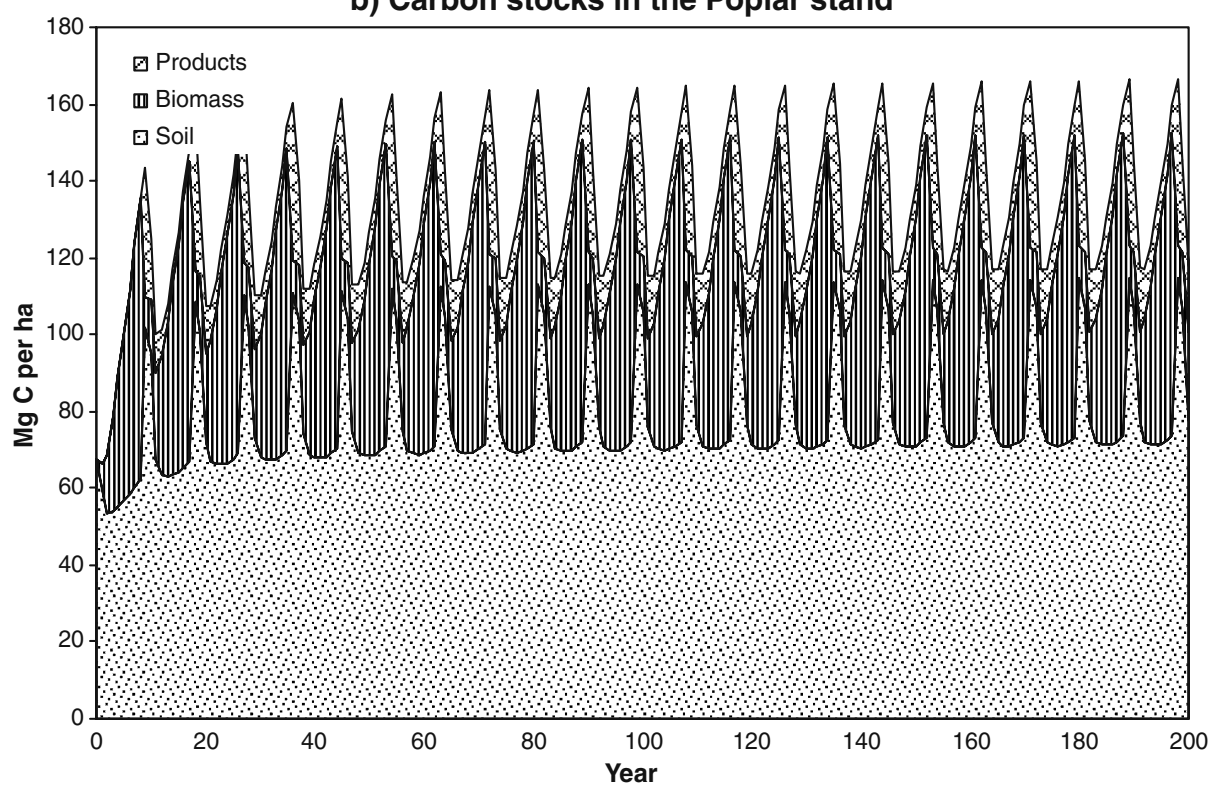

Fig. 5 Evolution of carbon stocks in different forest species a Eucalyptus, b Poplar, $\mathbf{c}$ Teak and $\mathbf{d}$ Sal

120 and 150 years ranged from 52 to $97 \mathrm{Mg} \mathrm{Cha}^{-1}$ for natural sal forests. An increased rotation length from 120 to 150 years increased the carbon sequestration of trees by $18 \%$ from 82 to $97 \mathrm{Mg} \mathrm{Cha}^{-1}$. This shows an increase in the carbon stock of trees with increasing rotation length due to the fact that the amount of wood harvested annually 
c) Carbon stocks in the Teak forest

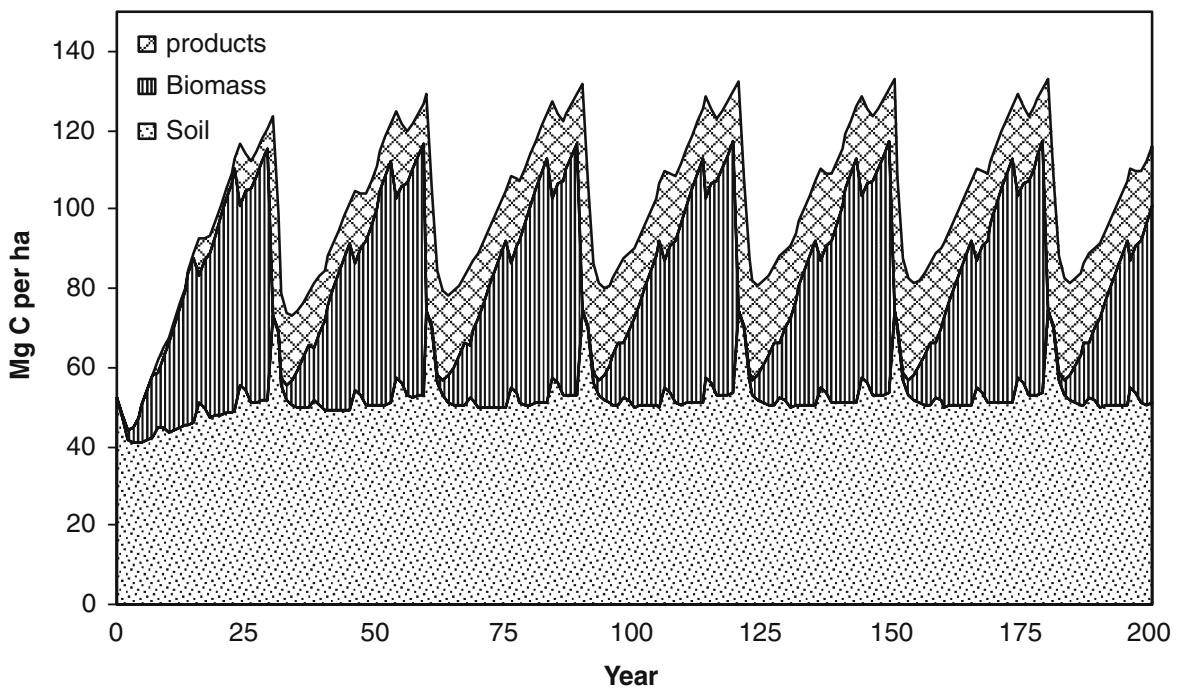

d) Carbon stocks in the Sal forest

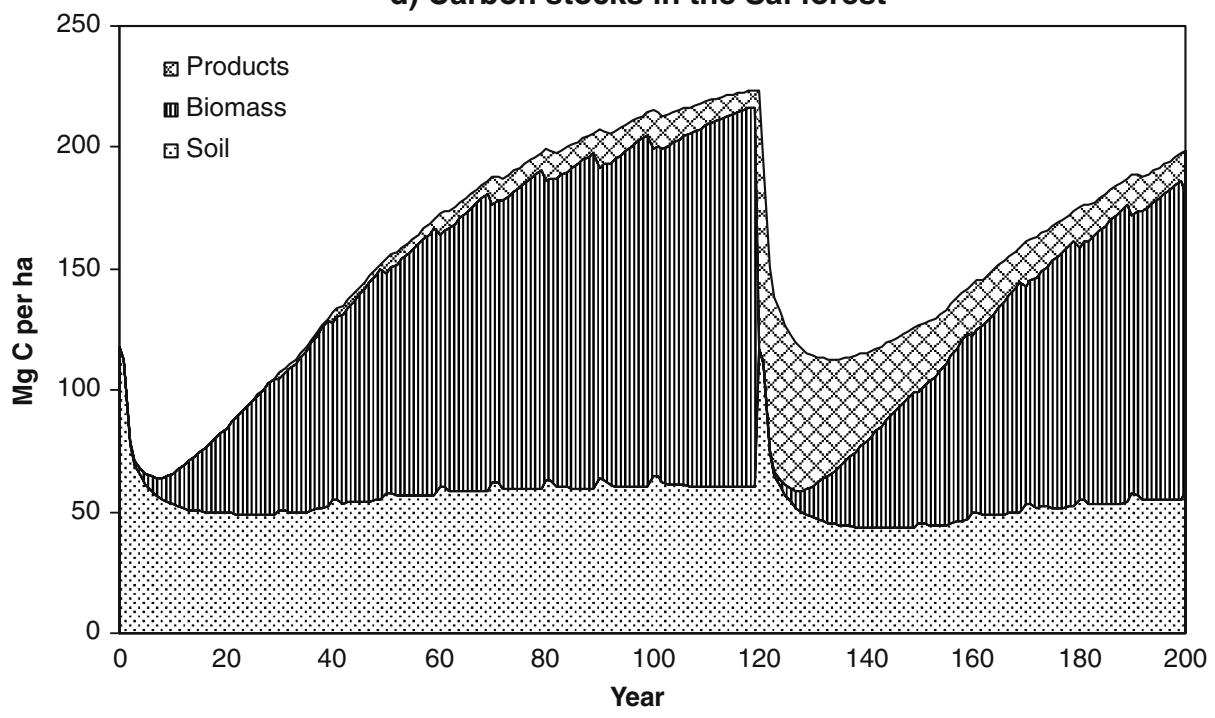

Fig. 5 (continued)

decreased with increasing rotation length. In general, soil carbon increased with the increase in the rotation length but the difference was less pronounced. The estimated total carbon stock in forest biomass and wood products ranged from 123 to $168 \mathrm{Mg} \mathrm{Cha}^{-1}$ indicating that increased rotation length yielded higher total carbon storage. In sal forests, the net primary productivity, i.e. the carbon flux to the system, was highest $\left(3.7 \mathrm{Mg} \mathrm{ha}^{-1} \mathrm{yr}^{-1}\right)$ when a 60 -year rotation length was applied, but (i.e., $1.7 \mathrm{Mg} \mathrm{ha}^{-1} \mathrm{yr}^{-1}$ at 150 years). The tree biomass produced a lot of litter but because of the decreased harvests, fewer harvest residues were produced. When the 150-year rotation length was applied instead of 


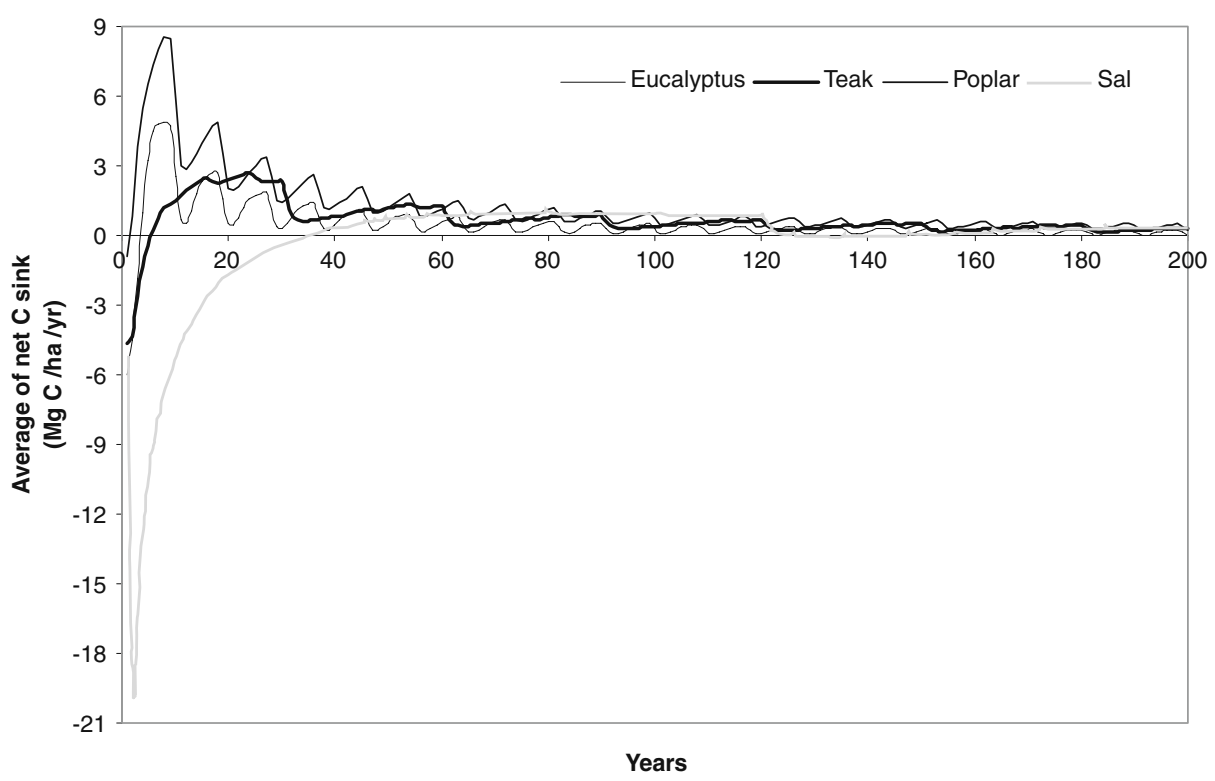

Fig. 6 Net effects in carbon stock since year 0 for four forest species

120 years, the average carbon stock of wood products decreased by $4 \mathrm{Mg} \mathrm{Cha}^{-1}$ (23\%). The carbon stocks in wood products were in the order of 22,19 and $15 \mathrm{Mg} \mathrm{Cha}^{-1}$ at 90 , 120 and 150 years rotation length respectively.

\subsubsection{Effect of changing thinning intensity}

Table 4 summarizes the simulated effects of changing thinning intensity on the carbon stocks of forest ecosystem and wood products of teak forests. The total carbon storage in the forest ecosystem was 116, 143, 140 and $121 \mathrm{Mg} \mathrm{Cha}^{-1}$ for "basic thinning", "no thinning", "low thinning" and "one heavy thinning", respectively. As compared to the

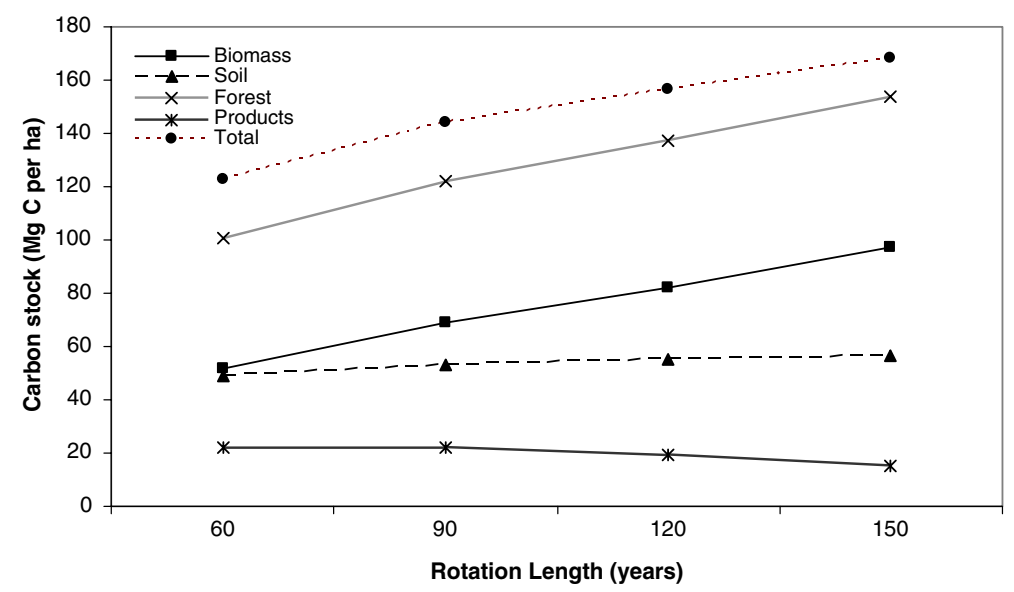

Fig. 7 Mean carbon stocks over different rotation periods in natural Sal stands 
Table 4 Total $\mathrm{C}$ stock in forest ecosystem (trees+soil) and $\%$ change in $\mathrm{C}$ stock as compared to basic thinning in teak stands at rotation length of 30 years

\begin{tabular}{llllll}
\hline Management regime & & $\begin{array}{l}\text { Basic } \\
\text { thinning }\end{array}$ & $\begin{array}{l}\text { No } \\
\text { thinning }\end{array}$ & $\begin{array}{l}\text { Low } \\
\text { thinning }\end{array}$ & $\begin{array}{l}\text { One heavy } \\
\text { thinning }\end{array}$ \\
\hline Total C in forest ecosystem (trees+soil) & $\mathrm{Mg} \mathrm{C} \mathrm{ha}^{-1}$ & 116 & 143 & 140 & 121 \\
& $\%$ & - & 23 & 21 & 4 \\
Total C above ground & $\mathrm{Mg} \mathrm{C} \mathrm{ha}^{-1}$ & 64 & 91 & 88 & 70 \\
& $\%$ & - & 42 & 38 & 9 \\
Total C in soil & $\mathrm{Mg} \mathrm{C} \mathrm{ha}^{-1}$ & 52 & 52 & 52 & 51 \\
Total C in products & $\mathrm{Mg} \mathrm{C} \mathrm{ha}^{-1}$ & 50 & 67 & 63 & 54 \\
& $\%$ & - & 34 & 26 & 8 \\
\hline
\end{tabular}

Estimated

"basic thinning" regime, the carbon stock in trees was $42 \%, 38 \%$ and $9 \%$ higher in "no thinning", "low thinning" and "one heavy thinning" regimes, respectively. The carbon stock in forest ecosystem was the highest when no thinning was applied. An increase in the thinning threshold increased carbon stock in trees, especially if the remaining basal area was increased. In the "no thinning" regime, the total carbon in harvested timber was $67 \mathrm{Mg} \mathrm{Cha}^{-1}$, which is $34 \%$ more than that under the basic thinning regime. Carbon stock in timber yield tended to increase when thinning was done earlier and of less intensity than in the basic thinning regime. The increment in carbon stock in harvested timber as compared to the "basic thinning" regime was $8 \%$ and $26 \%$ under "one heavy thinning" and "low thinning" regime, respectively (Table 4).

\section{Discussion \& conclusion}

Previous authors have estimated high potential of carbon storage in Indian forests, especially through raising plantations (e.g. Bhadwal and Singh 2002; Lal and Singh 2000; Manhas et al. 2006; Hooda et al. 2007; Baishya et al. 2009). Bhadwal and Singh (2002) used the Land Use and Carbon Sequestration Model (LUCS) model and estimated that under a regular plantation forestry scenario in India, $7 \mathrm{Pg}$ of carbon would be sequestered between 2000 and 2050. Lal and Singh (2000) estimated that with the currently reported rates of biomass productivity of natural forest cover $\left(1.1 \mathrm{Mg} \mathrm{ha}^{-1} \mathrm{yr}^{-1}\right)$ and plantations (3.2 $\mathrm{Mg} \mathrm{ha}^{-1} \mathrm{yr}^{-1}$ ), the carbon sequestration potential was in the range of 1.1 and $2.7 \mathrm{Pg} \mathrm{C}$, respectively, by the years 2020 and 2045 (cumulative carbon uptake from the atmosphere). Baishya et al. (2009) compared the carbon storage potential of natural semi-evergreen forest and sal plantation forest in the humid tropical region of northeast India. Their results suggest that the natural forest had lower aboveground biomass $\left(324 \mathrm{Mg} \mathrm{ha}^{-1}\right)$ than the plantation forest $\left(406.4 \mathrm{Mg} \mathrm{ha}^{-1}\right)$. Although both the forests had potential for carbon sequestration but the plantation forestry had an edge over the natural forest because of better silvicultural practices (Baishya et al. 2009).

The simulation results presented in our study reflects variation in tree species potential, site conditions and management regimes. Simulation also indicated the relative distribution of dry matter as $62 \%$ in stem, $8 \%$ in leaf, $15 \%$ in branch and $15 \%$ in root in Eucalyptus forest. In teak stands the relative distribution observed was $61 \%$ in stem, $4 \%$ in leaf, $20 \%$ in branch and $15 \%$ in roots. The relative distribution of dry matter in natural sal stands was 
$69 \%$ in stem, $3 \%$ in leaf, $9 \%$ in branch and $19 \%$ in root. This is a realistic allocation when compared with the figures in Bargali et al. (1992); Negi (1984) and Jha and Singh (1999).

The total long-term average carbon stocks in biomass and wood products was $156 \mathrm{Mg} \mathrm{Cha}^{-1}$ for slow growing long rotation forests and in the range of 101-134 Mg Cha ${ }^{-1}$ for fast growing short rotation forests. The carbon stock in wood products was in the range of $11-19 \mathrm{Mg} \mathrm{Cha}^{-1}$ or $10-12 \%$ of the total carbon stock. Average net annual carbon flux was in the range of $1 \mathrm{Mg} \mathrm{Cha}^{-1}$ for slow growing long rotation forests, $6-8 \mathrm{Mg} \mathrm{Cha}^{-1}$ for fast growing short rotation forests. In case of short rotation forests, the carbon pool in soil was higher than the carbon levels in living biomass. Post et al. (1990) reported that the ratio between SOC and biomass carbon is 2.5 to 3 times in the terrestrial ecosystem. However, in the tropical forest, the carbon in the soil is roughly equivalent to or less than the above-ground biomass due to degradation (cited in Ramachandran et al. 2007). Ravindranath et al. (1997) reported that the ratio of SOC and biomass carbon was 1.25 . In our study the ratio between SOC and biomass carbon was in the range of 0.7 to 2 . The present study indicates that in the plantations, the carbon content in the soil was almost double the biomass carbon but not 2.5 to 3 times the biomass carbon as recorded earlier. The fact that the SOC content was higher than the above-ground biomass carbon indicates that the sequestered SOC came from the original vegetation in the past before exploitation. Soil carbon estimates in sal forests were lower than the biomass carbon, which could be due to initial soil conditions and longer rotation periods.

Fast growing species seem to store large amounts of carbon according to one criteria, but results are limited according to another criterion, e.g., poplar plantations contain $73 \mathrm{Mg} \mathrm{Cha}^{-1}$ at the end of rotation but the long-term average is only $41 \mathrm{Mg} \mathrm{Cha}^{-1}$. Fast growing short rotation plantations usually show high net annual carbon fluxes during a short period, but they soon reach to relatively low equilibrium biomass and the high flux quickly tends to reach zero. Thus, the criterion of net annual $\mathrm{C}$ flux is only valid for the first rotation, as there is no net storage when the long-term average amount of carbon in biomass, soil and products has reached its equilibrium value.

Among the fast-growing species, Eucalyptus and poplar have gained importance with large-scale adoption by farmers and government agencies in plantations for meeting the rising demands for fuel wood and industrial consumption. Comparison with other forests of similar ages indicates that the present estimates of biomass for sal are evidently higher than the value $70 \mathrm{Mg} \mathrm{ha}^{-1}$ reported for sal forests that are more than 100 years old (Singh 1979). The values of aboveground biomass in the present study are comparable with those of Eucalyptus hybrid, $95 \mathrm{Mg} \mathrm{ha}^{-1}$ at 7 years, Negi and Sharma (1985); $21.9 \mathrm{Mg} \mathrm{ha}^{-1}$ at 10 years, Pandey et al. (1987), $263 \mathrm{Mg} \mathrm{ha}^{-1}$ for Oak forest, Negi et al. (1983) and 113-283 Mg ha ${ }^{-1}$ for Pinus roxburghii, Chaturvedi (1983). Poffenberger et al. (2001) reported sequestration levels varying between 0.5 and $3.4 \mathrm{Mg} \mathrm{Cha}^{-1} \mathrm{yr}^{-1}$ in communitybased teak forests in Harda forest division, Madhya Pradesh, figures which are comparable to our estimates. The results indicate that among the species studied, poplars have the highest potential to sequester carbon, followed by Eucalyptus plantations. These plantations hold promise for higher organic matter production in the Terai region. For a tropical country like India, having vast range of forest types, weather and soil conditions, it is not possible to select one forest type that is most suitable for carbon sequestration. Long rotation forests have larger long-term carbon storage in forest biomass and product pools and short rotation plantations, in addition to carbon storage rapidly produce biomass for meeting the demand for fuel and fibre, and thus have higher carbon emission mitigation potential.

The total carbon stock in the forest ecosystem increased with increasing rotation length. A 30-year increase in the rotation length from recommended 120 years increased the 
average carbon stock of forest ecosystem (trees + soil) by $12 \%$. In old forests, despite the increase in the rotation length, NPP may decrease due to the increased respiration burden caused by increasing woody biomass, decreased light interception, or a shift in carbon allocation from aboveground to belowground production (Smith and Resh 1999). Due to the increase in litter production and harvest residues, the carbon stock in soil also increased, thereby substantially enhancing the carbon sink function of forests. The longer rotation lengths mean decrease of harvesting possibilities and also of the amount of harvest residues that could be used to produce bioenergy. Goal of maximum carbon storage and production of more valuable saw logs can be achieved from longer rotation lengths. More research is needed on the carbon dynamics and end use of wood for small and long rotation species.

The results showed that the intensity of thinning regime changed the carbon stock of trees and products. Highest carbon stock (143 $\left.\mathrm{Mg} \mathrm{Cha}^{-1}\right)$ was achieved in "no thinning" regime. From an ecological perspective, if only carbon storage is the aim, "no thinning" could be preferred. But this is not a viable option, because increasing the carbon pool by way of zero thinning will not decrease emissions of fossil fuel since storing carbon is an indirect solution and will not decrease the need of fossil fuel for transportation or combustion and such patches could have high risks of forest fires, insects etc. (Erikson 2006). Moreover, from an economical perspective, there will be no wood available from thinning operations to replace fossil fuel for bioenergy and to the pulp industry. The "low thinning" regime also gave the higher carbon stock in the forest biomass $\left(140 \mathrm{Mg} \mathrm{Cha}^{-1}\right)$ as compared to "basic thinning". In our study, the management effect on carbon stock in trees was higher than the carbon stock in soil (which tends to be more stable). However, the carbon stocks also depend upon the tree species, site properties, spacing, climate conditions, age class distribution etc. (Vucetich et al. 2000; Pussinen et al. 2002). There are some detailed studies on thinning intensity and its effect on various species e.g., mixed and pure plantations in Costa Rica (Pitto et al. 2003), teak in Costa Rica (Kanninen et al. 2004), picea abies \& pinus sylvestris $L$. in Sweden (Erikson 2006) and picea abies in Norway (Nilsen and Strand 2008). Kanninen et al. 2004 suggests that for sawn timber productivity objectives, high intensity thinning offer great advantage over "low-thinned" or "no thinning" stands. Perez and Kanninen (2005) suggested that moderate and heavy thinning yielded the highest percentage of heartwood volume ( 25 to $30 \%$ of the total stem volume) suggesting that early stages teak stands could be managed under different thinning programmes without negatively affecting the quality of wood under humid tropical conditions. Extended rotation lengths and reduced thinning intensity could enhance the long-term capacity of forest ecosystems to sequester carbon. Our results on the effect of management practices on carbon stocks could not be compared to any measurements due to the lack of such results or of earlier studies based on Indian conditions. This also implies that more thorough and detailed data sets are required for obtaining more accurate results and making comparisons at the state and national levels. Future studies will also have to consider dynamics in both trees outside forests and soil for total terrestrial carbon dynamics.

Projected climate changes include strengthening of monsoon circulation, increases in surface temperature, and increases in the magnitude and frequency of extreme rainfall events. In a case study of Kerala (Achanta and Kanetkar 1996), results indicate that under the climate change scenarios, soil moisture is likely to decline and in turn reduce teak productivity from $5.40 \mathrm{~m}^{3} /$ ha to $5.07 \mathrm{~m}^{3} /$ ha. The study also shows that the productivity of moist deciduous forests could decline from $1.8 \mathrm{~m}^{3} /$ ha to $1.5 \mathrm{~m}^{3} /$ ha. Changes in forestry could potentially result in extinction of some species and loss of biodiversity. In semi-arid regions of Tropical Asia, tropical forests generally are sensitive to changes in temperature 
and rainfall, as well as changes in their seasonality. Fire is also influenced by these changes and would significantly affect the structure, composition, and age diversity of forests in the region. Fire frequency could be affected by the human activities like, slash and burn agriculture, as well as by variations in climate (e.g., longer or shorter dry seasons).

Our study does not include the criteria, e.g., a) reduction in carbon emissions through fossil fuel substitution using wood energy; b) carbon stock estimation of forest biomass and soil in mixed forests (e.g. dominated by sal) is also not evaluated; c) future changes in forest growth due to changes in environmental conditions and as a consequence of climate change. In recent years, the forest areas in India have stabilized, but location-specific deforestation and high annual plantation rates suggest big changes in the carbon cycle pattern, which cannot be captured using a national-scale approach. Species and usedependent carbon cycle estimates that also account for soil, wood products and energy usage can be gained using models such as CO2FIX. This requires parameters per species. There is a need to further investigate the full $\mathrm{C}$ cycle for all the important species in India and the management practices for sustainable production of biomass to replace fossil fuels and increase carbon stocks.

Open Access This article is distributed under the terms of the Creative Commons Attribution Noncommercial License which permits any noncommercial use, distribution, and reproduction in any medium, provided the original author(s) and source are credited.

\section{References}

Achanta AN, Kanetkar R (1996) Impact of climate change on forest productivity: a case study of Kerala, India. Paper presented at the Asian and Pacific Workshop on Climate Change Vulnerability and Adaptation Assessment, January 15-19, 1996, Manila, Philippines

Baishya R, Barik SK, Upadhaya K (2009) Distribution pattern of aboveground biomass in natural and plantation forests of humid tropics in northeast India. Trop Ecol 50(2):295-304

Ball JB, Pandey D, Hirai S (1999) Global overview of Teak plantations. Paper presented to the Regional Seminar, Site, Technology and Productivity of Teak plantations. Chiang Mai, Thailand 26-29 January 1999

Bargali SS, Singh SS, Singh RP (1992) Structure and function of an age series of Eucalyptus Plantations in Central Himalaya, Dry matter dynamics. Ann Bot 69:405-411

Bebarta KC (1999) Teak: ecology, silviculture, management and profitability. International book distributors, Dehradun

Bhadwal S, Singh R (2002) Carbon sequestration estimates for forestry options under different land-use scenarios in India. Curr Sci 83(11):1380-1386

Buekering PV, Sharma VK (eds) (1998) Waste Paper Trade and Recycling in India, Jodhpur. Scientific publishers, India

Burshel P, Kursten E, Larson BC, Weber M (1993) Present role of German forests and forestry in the national carbon budget and options to its increase. Water Air Soil Pollut 70:325-349

Champion HG, Seth SK (1968) A revised forest types of India. Manager of Publications, Government of India, Delhi

Chaturvedi OP (1983) Biomass structure, productivity and nutrient cycling in Pinus forest. Ph.D. Thesis. Kumaun University, Nanital, India, 347 pp

Chhabra A, Dadhwal VK (2004) Assessment of Major Pools and Fluxes of Carbon in Indian Forests. Climatic Change 64:341-360

Chhabra A, Palria S, Dadhwal VK (2002) Soil organic carbon pool in Indian forests. For Ecol Manage 5877:1-13

Dwivedi AP (1994) Forests: The ecological ramifications. International book distributors, Dehradun

Eggers T (2002) The impacts of manufacturing and utilisation of wood products on the European carbon budget. European Forest Institute. Internal Report 9

Erikson E (2006) Thinning operations and their impact on biomass production in stands of Norway spruce and Scots pine. Biomass Bioenergy 30:848-854 
Fang S, Xue J, Tang L (2007) Biomass production and carbon sequestration potential in poplar plantations with different management patterns. J Environ Manage 85:672-679

FAO (2003) State of the World's Forests. Food and Agriculture Organisation of the United Nations, Rome, p 126

FSI (1999) The State of the Forest Report. Forest Survey of India, Ministry of Environment and Forest, Govt. of India, Dehradun

Gupta HS (2009) Forest as carbon sink-Temporal analysis for Ranchi district. Indian J Forest 32(1):7-11

Haripriya GS (2000) Estimate of biomass in Indian forests. Biomass Bioenergy 19:245-258

Haripriya GS (2001) A frame work for carbon stored in Indian wood products. Environ Dev Sustain 3:229251

Harmon ME, Harmon JM, Ferrell WK, Brooks D (1996) Modelling carbon stores in Oregon and Washington forest products: 1900-1992. Climatic Change 33:521-550

Hooda N, Gera M, Andrasko K, Sathaye JA, Gupta MK, Vasistha HB, Chandran M, Rassaily SS (2007) Community and farm forestry climate mitigation projects: case studies from Uttaranchal, India. Mitig Adapt Strateg Glob Change 12(6):1099-1130

Forestry and Wildlife Statistics of India (2004) National Afforestation and Eco-Development Board, Ministry of Environment and Forest, Govt. of India

Intergovernmental Panel for Climatic Change (IPCC) (2000) Chapter 3: Afforestation, reforestation and deforestation activities. In: Watson R, Noble IR, Bolin B, Ravindranath NH, Verardo DJ, Dokken DJ (eds) Land use, land use change, and forestry. A special report of the IPCC. Cambridge University Press, Cambridge, p 377

IPCC (2001) Climate change 2001: the scientific basis, IPCC third assessment report, Working group I, Technical Summary. Cambridge University Press, Cambridge

IPCC (2007) Climate Change 2007: The Scientific Basis: IPCC fourth assessment report, Working Group I. Available online at http://www.ipcc.ch

Jha KK (1995) Structure and functioning of an age series of Teak (Tectona Grandis Linn.) plantations in Kumaon Himalayan Terai. Ph.D. Thesis. Kumaon University, Nainital

Jha KK, Singh JS (1999) Temporal Patterns of Bole Volume and Biomass of Young Teak Plantations Raised in Moist Deciduous Forest Region, India. Int J Ecol Environ Sci 25:77-184

Jha MN, Gupta MK, Alok S, Rajesh K (2003) Soil organic carbon store in different forests in India. Indian Forester 129(6):714-724

Kanninen M, Perez D, Montero M, Edgar V (2004) Intensity and timing of the first thinning of Tectona grandis plantation in Costa Rica: results of a thinning trial. For Ecol Manage 203:89-99

Karjalainen T, Kellomäki S, Pussinen A (1994) Role of wood-based products in absorbing atmospheric carbon. Silva Fennica 28(2):67-80

Karjalainen T, Pussinen A, Liski J, Nabuurs GJ, Eherd M, Eggers T, Sonntag M, Mohren GMJ (2002) An approach towards an estimate of the impact of forest management and climate change on the European forest sector budget: Germany as a case study. For Ecol Manage 162(1):87-103

Karjalainen T, Pussinen A, Liski J, Nabuurs GJ, Eggers T, Lapvetelainen T, Kaipainen T (2003) Scenario analysis of the impact of forest management and climate change on the European forest sector carbon budget. For Policy Econ 5:141-155

Kaul M, Dadhwal VK, Mohren GMJ (2009) Land use change and net C flux in Indian forests. For Ecol Manage 258:100-108

Kaul M, Mohren GMJ, Dadhwal VK (2010a) Phytomass carbon pool of Indian forests and trees outside forests (Submitted to Climatic Change)

Kaul M, Mohren GMJ, Dadhwal VK (2010b). Carbon storage versus fossil fuel substitution: a climate change mitigation option for two different land use categories based on long and short rotation forestry in India. Mitig Adapt Strategies Glob Chang 15:395-409

Kimmins JP, Mailly D, Seely B (1999) Modelling forest ecosystem net primary production: the hybrid simulation approach used in FORECAST. Ecol Model 122:195-224

Kurz WA, Apps MJ, Webb TM, McNamee PJ (1992) The carbon budget of the Canadian forest sector: Phase I. Forestry Canada, Northw. Reg., North. For. Cent., Edmonton, AB. Inf. Rep. NOR-X-326

Lal R (1999) Soil management and restoration for C sequestration to mitigate the accelerated greenhouse effect. Prog Environ Sci 1(4):307-326

Lal M, Singh R (2000) Carbon sequestration potential of Indian forests. Environ Monit Assess 60:315-327

Liski J, Nissinen A, Erhard M, Taskinen O (2003) Climatic effects on litter decomposition from arctic tundra to tropical rainforest. Glob Change Biol 9:575-584

Lodhiyal LS, Lodhiyal N (1997) Variation in Biomass and Net primary productivity in short rotation high density central Himalayan poplar plantations. For Ecol Manage 98:167-179

Lodhiyal LS, Singh RP, Singh SP (1995) Structure and function of an age series of Poplar plantations in Central Himalaya: I. Dry matter dynamics. Ann Bot 76:191-199 
Manhas RK, Negi JDS, Kumar R, Chauhan PS (2006) Temporal assessment of growing stock, biomass and carbon stock of Indian forests. Climatic Change 74:191-221

Masera OR, Garza-Caligaris JF, Kanninen M, Karjalainen T, Liski J, Nabuurs GJ, Pussinen A, de Jong BHJ, Mohren GMJ (2003) Modelling carbon sequestration in afforestation, agroforestry and forest management projects: the CO2FIX V.2 approach. Ecol Model 164:177-199

Nabuurs GJ, Mohren GMJ (1993) Carbon fixation through forestation activities: a study of the carbon sequestering potential of selected forest types, commissioned by the Foundation Face. Institute for Forestry and Nature Research, Wageningen. IBN Research Report 93/4

Nabuurs GJ, Schelhaas MJ (2002) Carbon profiles of forest types across Europe assessed with CO2FIX. Ecol Indic 1:213-223

Negi JDS (1984) Biological Productivity and Cycling of Nutrients in Managed and Man Made Ecosystems. Ph.D Thesis, Garhwal University, Srinagar. India

Negi SS (1996) Teak (Tectona grandis). Book

Negi JDS, Chauhan PS (2002) Green house gases mitigation potential by Sal (Shorea Robusta Gaertn. f.) forest in Doon Valley. Indian Forester 128(7):771-778

Negi JDS, Sharma SC (1985) Biomass production and nutrient distribution in an age series of Eucalyptus hybrid plantation in Tamil Nadu. Indian Forester 111(12):1111-1122

Negi KS, Rawat YS, Singh JS (1983) Estimation of biomass and nutrient storage in a Himalayan temperate forest. Can J For Res 13:1185-1196

Negi JDS, Manhas RK, Chauhan PS (2003) Carbon allocation in different components of tree species of India: a new approach for carbon estimation. Curr Sci 85(11):1528-1531

Nilsen P, Strand LT (2008) Thinning intensity effects on carbon and nitrogen stores and fluxes in a Norway Spruce (Picea abies (L.) Karst.) stand after 33 years. For Ecol Manage 256:201-208

Pandey D (2008) India's forest resource base. Int Forest Rev 10(2):116-124

Pandey MC, Tandon VN, Rawat HS (1987) Organic matter production and distribution of nutrient in Eucalyptus hybrid plantation ecosystem in Karnataka. Indian Forester 114(11):713-724

Parton WJ, Schimel DS, Cole CV, Ojima DS (1987) Analysis of factors controlling soil organic matter levels in Great Plains grasslands. Soil Sci Soc Am J 51:1173-1179

Peng C, Liu J, Dang Q, Apps MJ, Jiang H (2002) TRIPLEX: a generic hybrid model for predicting forest growth and carbon and nitrogen dynamics. Ecol Model 153:109-130

Perez D, Kanninen M (2005) Effect of Thinning on stem form and wood characteristics of teak (Tectona Grandis) in a humid tropical site in Costa Rica. Silva Fennica 39(2):217-225

Pingoud K, Perälä AL, Pussinen A (2001) Carbon dynamics in wood products. Mitig Adapt Strateg Glob Change 6(2):91-111

Pitto D, Montagnini F, Ugalde L, Kanninen M (2003) Growth and effects of thinning of mixed and pure plantations with native trees in humid tropical Costa Rica. For Ecol Manage 177:427-439

Poffenberger M, Ravindranath NH, Pandey DN, Murthy IK, Bist R, Jain D (2001) Communities and climate change: The clean development mechanism and village based restoration in Central India - a case study from Harda forest Division, Madhya Pradesh, India

Post WM, Pengh TH, Emanuel W, King AW, Dale VH, Delnglis (1990) The global carbon cycle. Atmos Sci 78:310-326

Price DT, Peng CH, Apps MJ, Halliwell DH (1999) Simulating effects of climate change on boreal ecosystem carbon pools in central Canada. J Biogeogr 26:1237-1248

Pussinen A, Karjalainen T, M“akip“a”a R, Valsta L, Kellom“aki S (2002) Forest carbon sequestration and harvests in Scots pine stand under different climate and nitrogen deposition scenarios. For Ecol Manage 158(1-3):103-115

Ramachandran A, Jayakumar S, Haroon RM, Bhaskaran A, Arockiasamy DI (2007) Carbon sequestration: estimation of carbon stock in natural forests using geospatial technology in the Eastern Ghats of Tamil Nadu, India. Curr Sci 92(3):323-331

Ravindranath NH, Somasekhar BS, Gadgil M (1997) Carbon flows in Indian forest. Climatic Change 35 (3):297-320

Ravindranath NH, Sudha P, Sandhya R (2002) Forestry for Sustainable Biomass Production and Carbon Sequestration in India. Mitig Adapt Strateg Glob Change 6:233-256

Schelhaas MJ, Esch PW Van, Groen TA, De Jong BHJ, Kanninen M, Liski J, Masera O, Mohren GMJ, Nabuurs GJ, Palosuo T, Pedroni L, Vallejo A, Vilen T (2004) CO2FIX v. 3.1-A framework for quantifying carbon sequestration in forest ecosystems. Wageningen, Alterra rapport 1068

Seely B, Welham C, Kimmins H (2002) Carbon sequestration in a boreal forest ecosystem: results from the ecosystem simulation model, FORECAST. For Ecol Manage 169:123-135

Singh B (1979) Ecology of Pinus Patula planted in Darjeeling Himalaya. Ph.D. Thesis. Banaras Hindu University, Varanasi 
Singh TP (2003) Potential of farm forestry in carbon sequestration. Indian Forester 129(7):839-843

Skog KE, Nicholson GA (1998) Carbon cycling through wood products: the role of wood and paper products in carbon sequestration. For Products J 48(7/8):75-83

Smith FW, Resh SC (1999) Age-related changes in production and below-ground carbon allocation in Pinus Contorta forests. For Sci 45(3):333-341

Tewari DN (1995a) A monograph on sal. Vedam Publications, India

Tewari DN (1995b) A monograph on teak. Vedam Publications, India

Updegraff K, Baughman MJ, Taff SJ (2004) Environmental benefits of cropland conversion to hybrids poplar: economic and policy considerations. Biomass Bioenergy 27:411-428

Vucetich JA, Reed DD, Breymeyer A, Deg'orski M, Mroz GD, Solon J, Roo-Zielinska E, Noble R (2000) Carbon pools and ecosystem properties along a latitudinal gradient in northern Scots pine (Pinus sylvestris) forests. For Ecol Manage 136:135-145

Winjum JK, Brown S, Schlamadinger B (1998) Forest harvest and wood products: Sources and sinks of atmospheric carbon dioxide. For Sci 44(2):272-284 